\title{
Hydrogeochemical characterization of an evaporite karst area affected by sinkholes (Ebro Valley, NE Spain)
}

\author{
P. ACERO $^{|1|}$ F. GUTIÉRREZ ${ }^{|1|}$ J.P. GALVE ${ }^{|1|}$ L.F. AUQUÉ ${ }^{11 \mid}$ D. CARBONEL ${ }^{|1|}$ \\ M.J. GIMENO $^{|1|}$ J.B. GÓMEZ M.P. ASTA ${ }^{|2|}$ Y. YECHIELI
}

| 1 | Earth Sciences Department, University of Zaragoza

c/Pedro Cerbuna, 12, 50009 Zaragoza, Spain. Acero E-mail: patriace@unizar.es. Tel: +34976761067 / Fax: +34976761106 CERI Research Centre on Prevention Prediction and Control of Geological Risks. Sapienza University of Rome

Piazza U. Pilozzi, 9, 00038, Valmontone, Rome (Italy). E-mail: gianluca.bianchifasani@uniroma1.it

I2 I Instituto Andaluz de Ciencias de la Tierra (IACT) (CSIC-UGR)

Avda. de las Palmeras, 4; 18100 Armilla, Granada, Spain.

| 3 | Geological Survey of Israel, Jerusalem 95501, and Department of Environmental Hydrology \& Microbiology, Zuckerberg Institute for Water Research, Blaustein Institutes for Desert Studies, Ben Gurion University of the Negev, Sede Boqer, Israel

\section{A B S T R A C T}

The main processes controlling the hydrochemistry of an alluvium-covered evaporite karst area with high sinkhole risk (Ebro Valley, NE Spain) are examined by means of multivariate analyses (Principal Component Analysis and Hierarchical Cluster Analysis), ion correlations and geochemical speciation-solubility calculations. The hydrogeochemistry of the studied system seems to be governed by the interaction between the groundwater from the salt-bearing evaporitic karst aquifer and from the overlying Ebro River alluvial aquifer. The observed hydrochemical features in the alluvial-karst aquifer system are mainly determined by the relative contribution of gypsum/anhydrite and halite dissolution, showing a wide spectrum from relatively fresh recharge waters (mainly irrigation waters) to highly evolved groundwater from the evaporitic aquifer. The variability of these contributions is especially evident at sinkhole ponds which, in some cases, seem to be associated with discharge areas of the karst aquifer in the valley bottom alluvium. Calculated saturation indexes suggest that, in contrast to gypsum, the amounts of halite in the sampled portions of evaporitic aquifer are not large enough to attain equilibrium, which is consistent with the predominance of gypsum/anhydrite reported for these materials. Furthermore, the observed $\mathrm{Na}: \mathrm{Cl}$ and $\mathrm{Ca}: \mathrm{SO} 4$ correlations and stoichiometries suggest that other possible processes, such as glauberite dissolution or $\mathrm{Na} / \mathrm{Ca}$-exchange, generally play a minor role (compared to halite and gypsum dissolution) in this system. Another important process in the system is the dissolution of carbonate minerals (dolomite and, possibly, calcite) fostered by the input of $\mathrm{CO} 2(\mathrm{~g})$, which is probably produced by pedogenic processes. Dolomite dissolution seems to be particularly relevant in the evaporitic materials probably due to dedolomitisation triggered by gypsum/anhydrite dissolution. 


\section{INTRODUCTION}

The subsurface dissolution of soluble minerals in carbonate and evaporitic materials by groundwater may cause the gravitational deformation and internal erosion of the overlying sediments, eventually leading to the settlement of the ground surface. Commonly, the geomorphic expression of these hazardous subsidence phenomena corresponds to closed depressions designated as sinkholes or dolines (Williams, 2004; Beck, 2005; Waltham, 2005; Gutiérrez et al., 2008b).

The Ebro Valley in the outskirts of Zaragoza city (NE Spain) is most probably the area in Europe where subsidence risk related to evaporite dissolution has the greatest economic impact. In this sector, sinkholes related to the karstification of the highly soluble Tertiary Zaragoza Formation (gypsum/ anhydrite, halite, glauberite) underlying Quaternary alluvium show a high spatial and temporal frequency (Gutiérrez et al., 2008a; Galve et al., 2009). The occurrence and reactivation of sinkholes in this mantled karst setting have lead to the demolition of many buildings and affect numerous linear infrastructures, including the high-speed Madrid-Barcelona railway (Guerrero et al., 2008b; Galve et al., 2009; Gutiérrez et al., 2009).

The effective management of the subsidence risk requires a detailed knowledge of the processes and factors involved in sinkhole development. Among other features, the mineralogy, hydrochemistry and hydrogeology of the target areas need to be well-known in order to understand the processes leading to karstification (Lamont-Black et al., 2002). Nevertheless, the vast majority of earlier works dealing with these processes have been carried out in carbonate karst aquifers (e.g. López-Chicano et al., 2001; Aquilina et al., 2003, 2005, 2006 and references therein; Barbieri et al., 2005; Tuccimei et al., 2005; Moore et al., 2009; Barberá and Andreo, 2012 and references therein; Bicalho et al., 2012). Most of the studies on evaporite karst terrains affected by sinkholes are focused on geomorphological aspects and the associated environmental problems (e.g. Klimchouk et al., 1996; Calaforra and Pulido-Bosch, 1999; Johnson and Neal, 2003; Gutiérrez et al., 2008c; Cooper and Gutiérrez, 2013 and references in all of them), and works addressing the hydrochemical and geochemical factors controlling the dissolution processes involved in sinkhole development are quite scarce (e.g. Kaçaroglu et al., 2001; Günay, 2002; Land, 2003; Lamont-Black et al., 2005; Yechieli et al., 2006; Omelon et al., 2006; Chiesi et al., 2010; Fidelibus et al., 2011; Apaydin and Aktas, 2012).

In spite of the relevant engineering and economic implications of the sinkhole hazard related to evaporite dissolution in the Ebro Valley, the relationships between the hydrogeology and geochemistry of the area and the dissolution phenomena remain poorly understood (Sánchez et al., 2004; Jiménez-Torrecilla et al., 2004). Moreover, to the best of our knowledge, the hydrogeochemical features and controls of this evaporite karst have not been comprehensively addressed by any earlier investigation. Thus, the main goal of this study is to obtain a better understanding of the hydrogeology and hydrogeochemistry of this area in relation to the features and processes involved in the development of sinkholes. The hydrogeochemistry at several types of water points (springs, wells, sinkhole ponds and ditches) is thoroughly examined with the assistance of multivariate analyses, examination of ion correlations and geochemical speciation-solubility calculations. Moreover, the relationships between the observed hydrochemical features, possible water-rock interaction processes, the composition of the evaporitic bedrock, and hydrogeological variables, are analysed. As a result, a general hydrochemical model is proposed, which will constitute the basis for future detailed studies aimed at exploring how this type of investigations may contribute to a more efficient analysis and management of the sinkhole risk.

\section{MATERIALS AND METHODS}

\section{Geological setting and climate}

The studied $60 \mathrm{~km}$ long reach of the Ebro Valley is located in the central sector of the Ebro Tertiary Basin, which constitutes the southern foreland basin of the Pyrenees (Fig. 1A). Here, the Ebro Valley has been carved in subhorizontally lying evaporites of the Oligo-Miocene Zaragoza Formation, deposited in an extensive high-salinity playa-lake (Quirantes, 1978, Ortí and Salvany, 1997). This evaporitic formation reaches more than $850 \mathrm{~m}$ in thickness (Torrescusa and Klimowitz, 1990). In the subsurface the formation is primarily composed of anhydrite (CaSO4)/ gypsum $(\mathrm{CaSO} 4 \cdot 2 \mathrm{H} 2 \mathrm{O})$, halite $(\mathrm{NaCl})$ and glauberite ( $\mathrm{Na} 2 \mathrm{Ca}[\mathrm{SO} 4] 2)$, with interlayered marls and mudrocks including calcite $(\mathrm{CaCO} 3)$, dolomite $(\mathrm{CaMg}(\mathrm{CO} 3) 2)$ and quartz (SiO2) grains (Salvany et al., 2007 and references therein; Guerrero et al., 2008a,b, in press). Halite and glauberite beds situated close to the surface, reach as much as $75 \mathrm{~m}$ and $30 \mathrm{~m}$ in thickness, respectively (Salvany, 2009). In outcrops, the evaporitic succession exhibits around $300 \mathrm{~m}$ of laminated and nodular secondary gypsum derived from the hydration of anhydrite or the replacement of glauberite (Fig. 1B). The evaporitic formation changes laterally into impervious and insoluble clay facies in the eastern sector of the studied area (Fig. 1A).

In the studied reach of the valley, the terrace and pediment deposits overlying the evaporitic materials may reach $80 \mathrm{~m}$ and fill kilometer-scale basins generated by dissolution-induced syn-sedimentary subsidence (Guerrero et al., in press and references therein). These 

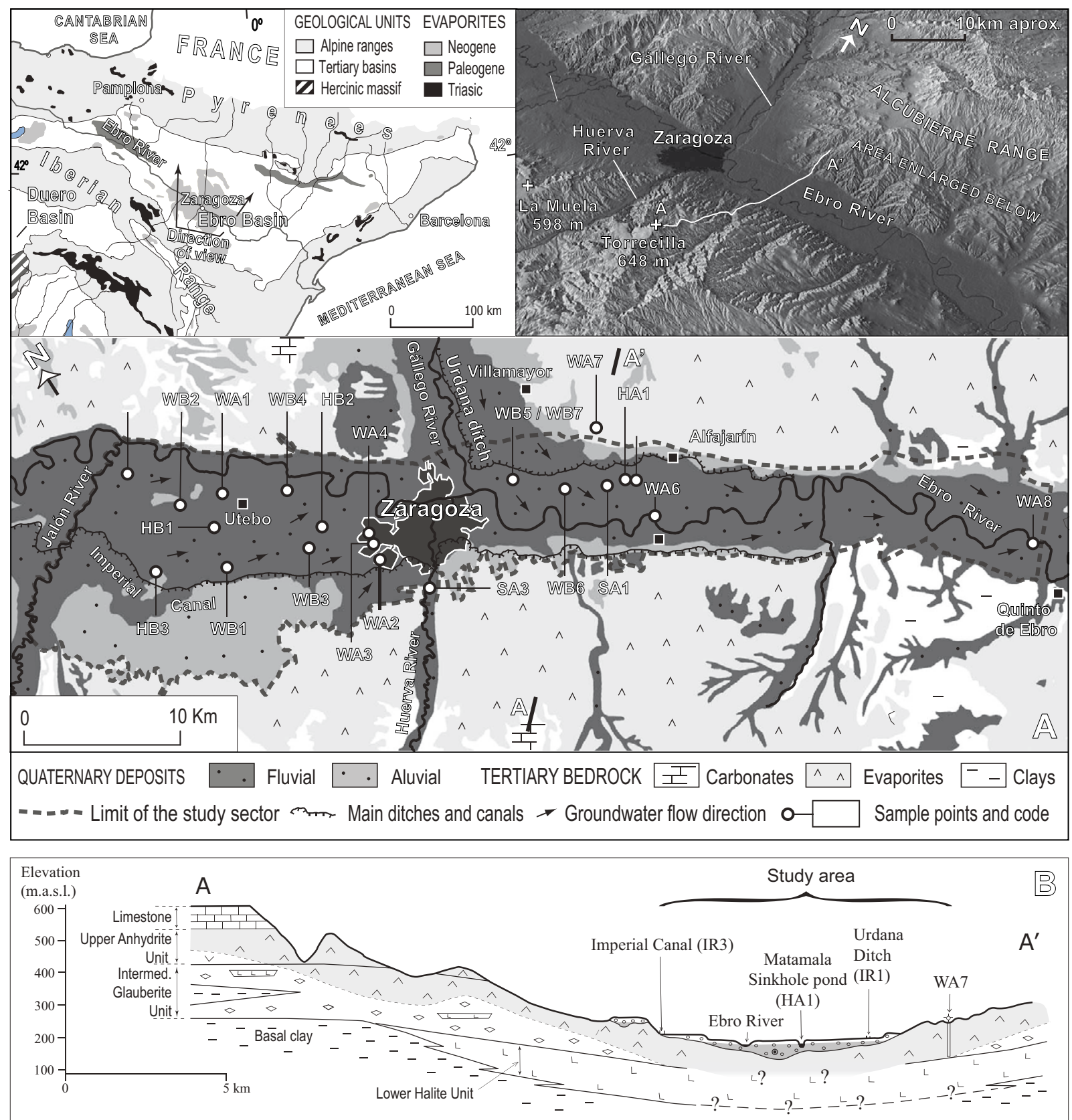

LITHOFACIES $\square$ Limestone $\triangle$ S Secondary gypsum $\square$ Anhydrite $\diamond$ Glauberite $\square$ Halite $\square$ Clay $\square$ Alluvial aquifer $\square$ Weathering zone

FIGURE 1 A) Location and geological settings of the study area and position of the selected sampling points for hydrochemicalcharacterisation. B) Schematic cross-section perpendicular to the Ebro Valley downstream of Zaragoza city, showing the general distribution of the main lithostratigraphic units and the weatheringzone in whichanhydriteand glauberiteare replaced by secondarygypsum. Thesection is based on boreholedatafromthesouthern margin of the valley (Salvany, 2009) and assummes a roughly symmetric configuration at both sides of the valley, excavated along the axial zone of a very gentle syncline.

alluvial deposits mainly consist of gravels dominated by carbonate and siliciclastic materials with a sand-silt matrix, frequently cemented by carbonates.

Geomorphological studies and the analysis of paleosubsidence structures reveal that sinkhole formation in this area has been related to: i) progressive sagging resulting from interstratal karstification of glauberite and halite units; ii) upward propagation of cavities developed within the evaporite bedrock by progressive rock collapse; iii) upward propagation of voids through the alluvial mantle by soil cavity collapse and downward migration of detrital sediments into dissolutional voids (Gutiérrez et al., 2008a, Guerrero et al., 2008a,b, in press). Some of the sinkholes in the studied area are permanently filled with phreatic waters (Fig. 2) and, therefore, represent a valuable source of information on the hydrochemical and hydrogeological features of the alluvial-karst aquifer system. 


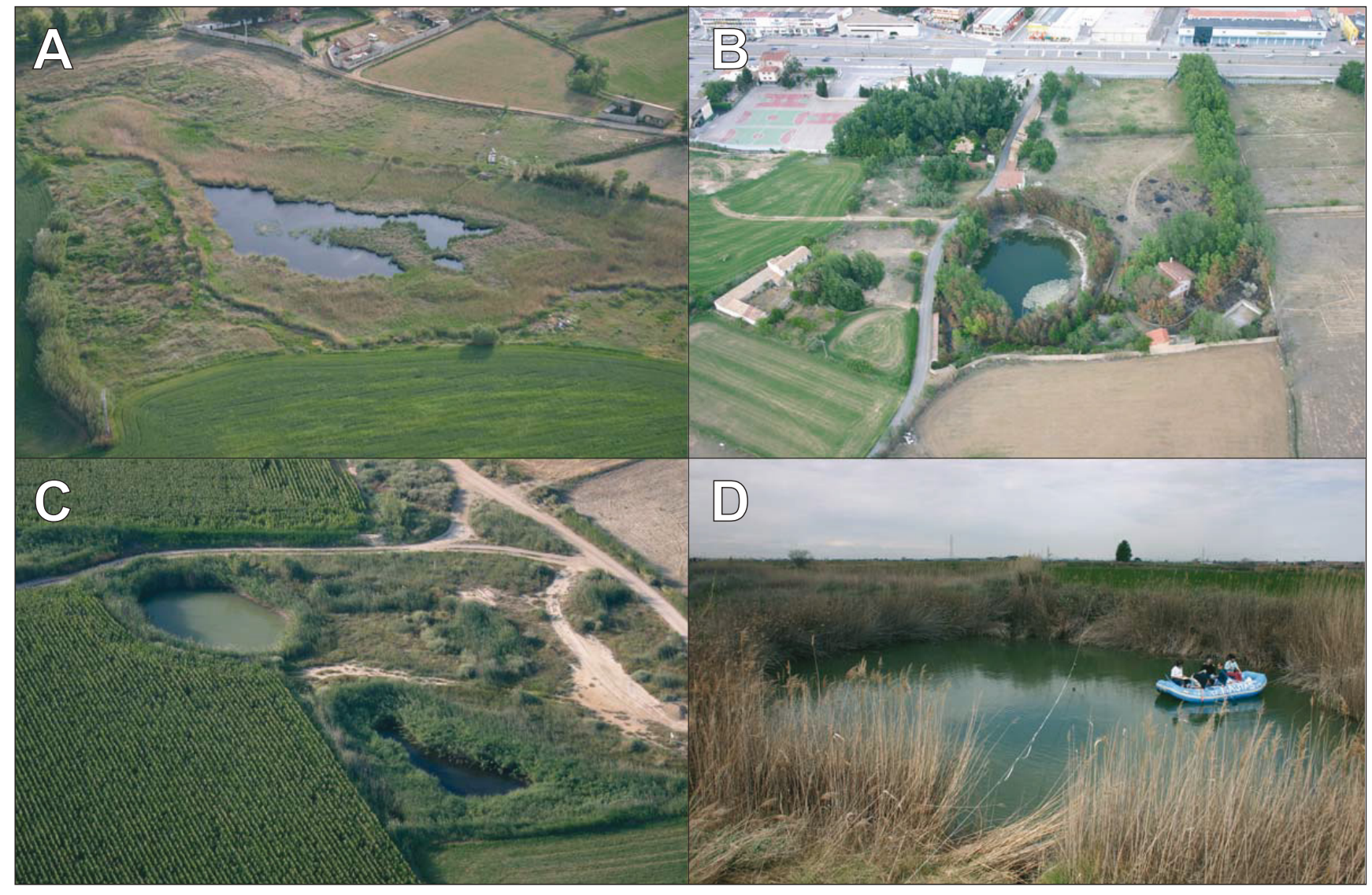

FIGURE 2 Images of some of the sampled permanent sinkhole ponds. A) Ojo del Fraile, a shallow lake (around 240m of maximum length) developed in a sagging sinkhole with nested collapse dolines (sampling point HB1). B) Torre del Chocolatero collapse sinkhole and pond (sampling point HB2). A maximum water depth of $6.6 \mathrm{~m}$ was measured in April 2009 in this pond (around 55m of maximum length). C, D) Ojos de Matamala flooded collapse sinkholes. This roughly circular pond (sampling point HA1) is 30m in diameter and 3.5m deep (as measured in April 2009).

The climate in this region is Mediterranean with strong continental influence, characterized by hot summers and cold winters. The average annual precipitation in Zaragoza area is around $340 \mathrm{~mm}$ and the mean monthly temperature ranges from $9^{\circ} \mathrm{C}$ to $21^{\circ} \mathrm{C}$ (Ninyerola et al., 2005). Precipitation shows a considerable inter-annual variability and a significant proportion corresponds to intense, short-duration convective storms that commonly occur in spring and autumn. The year 2011, corresponding to the sampling campaing carried out specifically for this study, showed a total precipitation of $315 \mathrm{~mm}$, indicating a slightly dryer year in relation to the average. The mean annual reference evapotranspiration in Ebro Valley exceeds $1150 \mathrm{~mm}$, indicating a negative water balance of more than $800 \mathrm{~mm}$ and, therefore, a climate characterized by semiarid conditions (Diputación General de Aragón, 2007).

\section{Hydrogeology of the studied area}

The hydrogeology of the area is characterized by two main interconnected and unconfined aquifers: i) the alluvial aquifer, composed by the alluvium underlying the valley bottom and the associated terrace deposits at the valley margins; ii) the karst aquifer developed in the salt-bearing evaporitic bedrock, which discharges in the previous one. The Ebro River and the associated valley bottom alluvium act as the base level for the alluvial-karst aquifer system (Durán et al., 2005) (Fig. 1A, B).

Very little is known about the karst aquifer developed in the fractured and karstified evaporitic bedrock. Although some authors assumed that it behaves as an aquitard (e.g. Martín, 1993), multiple lines of evidence indicate that is has a considerable permeability related to dissolution processes (Gutiérrez et al., 2007, Guerrero et al., 2008b; Galve et al., 2009). The recharge of the evaporitic aquifer occurs through infiltration of irrigation and precipitation water in bedrock outcrops and in local perched alluvial deposits located on the valley flanks. The groundwater that flows through the saltbearing evaporitic bedrock, attaining a progressively higher mineralization, ultimately discharges into the floodplain alluvium, as evidenced by the frequent presence in this aquifer of highly-saline waters associated with springs, wells and sinkhole ponds. Some authors have proposed that there may be areas of preferential discharge of the evaporite karst aquifer into the overlying alluvial aquifer (Sánchez et al., 2004; Jiménez-Torrecilla et al., 2004; Gutiérrez et al., 2007).

The water balance for the Ebro alluvial aquifer in the studied reach of the valley indicates that around $90 \%$ of 
the recharge is related to irrigation (Durán et al., 2005). This is the main factor controlling the seasonal variations in the watertable, which may rise several meters on average by the end of the irrigation season (August, September), during the low flow period of the Ebro River.

\section{Hydrochemical characterisation of the studied area}

\section{Selection of water points for hydrochemical characterisation}

In order to characterize the main hydrochemical features of the Ebro alluvial aquifer and to explore its relationship with the evaporitic karst aquifer in the study area, time series of hydrochemical data from 25 sampling points were included in this study (Table 1). The selection of water points was intended to cover the whole study area and to represent different types of water points (wells, springs, sinkhole ponds, ditches and the Ebro River). As displayed in Table 1 , the hydrochemical information from some of the points could be obtained from the public database of the Ebro Waters Authority (Confederación Hidrográfica del Ebro; $\mathrm{CHE}$ ). For the rest of sampling points included in this work, between 3 and 7 sampling surveys were carried out between January 2011 and January of 2012. During these surveys,

TABLE 1 1 Main features of the selected water points sampled for the hydrochemical analyses of the study area. The location of the points is shown in Figure 1. The codes of the sampling points consist of two capital letters followed by a number. The first capital letter indicates if the point corresponds to a well (W--), a spring (S--) or a pond ( $\left.\mathrm{H}_{--}\right)$. The second letter is used to indicate if the water at that point can be considered as relatively concentrated (-A-) or diluted (-B-) compared to the average TDS of the study area, which is around 1600 $\mathrm{mg} / \mathrm{l}$. Additionally, IR points correspond to irrigation waters. Finally, the numbers allow differentiating the different points of each type.

\begin{tabular}{|c|c|c|c|c|c|c|c|}
\hline Sampling point & Type of water point & $\begin{array}{c}\text { Origin of } \\
\text { hydrochemical } \\
\text { information }\end{array}$ & $\begin{array}{l}\text { Alluvial aquifer } \\
\text { thickness }(m)^{(3)}\end{array}$ & $\begin{array}{l}\text { Probable } \\
\text { sampled } \\
\text { aquifer }^{(4)}\end{array}$ & $\begin{array}{l}\text { Well depth } \\
\qquad(\mathrm{m})^{(3)}\end{array}$ & $\begin{array}{l}\text { Watertable } \\
\text { average } \\
\text { depth }(m)^{(3)}\end{array}$ & $\begin{array}{l}\text { Elevation } \\
(\text { (m.a.s.l.) })^{(5)}\end{array}$ \\
\hline WA1 & Pumping well & (1) & 10 & Mixing & 15 & 2 & 209 \\
\hline WA2 & Pumping well & (2) & 37 & Evaporitic & 70 & 37.5 & 239 \\
\hline WA3 & Pumping well & (2) & 30 & Mixing & 40 & 15 & 218 \\
\hline WA4 & Pumping well & (2) & 20 & Mixing & 40 & 10 & 207 \\
\hline WA5 & Pumping well & (1) & 12 & Mixing & 23 & 8 & 217 \\
\hline WAG & Pumping well & (1) & $5-10$ & Mixing & 15 & 5 & 179 \\
\hline WA7 & Pumping well & (2) & n.a. & Evaporitic & 101 & n.a. & 237 \\
\hline WA8 & Pumping well & (1) & n.a. & Mixing & 15 & 2.5 & 156 \\
\hline WB1 & Pumping well & (1) & 35 & Mixing & 38 & 18 & 237 \\
\hline WB2 & Pumping well & (1) & 6 & Mixing & 14 & 7 & 219 \\
\hline WB3 & Pumping well & (1) & $>52$ & Alluvial & 52 & 20 & 229 \\
\hline WB4 & Pumping well & (1) & 13 & Alluvial & 14.7 & 3 & 205 \\
\hline WB5 & Pumping well & (1) & $>25$ & Alluvial & 10 & 4.5 & 191 \\
\hline WB6 & Pumping well & (1) & $>12.4$ & Alluvial & 12.4 & 3.5 & 187 \\
\hline WB7 & Pumping well & (2) & $>25$ & Alluvial & 10 & 4.5 & 191 \\
\hline SA1 & Spring & (1) and (2) & 25 & Unknown & - & - & 181 \\
\hline SA2 & Spring & (2) & 25 & Unknown & - & - & 179 \\
\hline SA3 & Spring & (1) & 5 & Unknown & - & - & 236 \\
\hline HA1 & Sinkhole pond & (2) & 25 & Unknown & - & - & 181 \\
\hline HB1 & Sinkhole pond & (2) & 15 & Unknown & - & - & 216 \\
\hline HB2 & Sinkhole pond & (2) & 20 & Unknown & - & - & 206 \\
\hline HB3 & Gravel pit pond & (2) & 15 & Alluvial & - & - & 236 \\
\hline IR1 & $\begin{array}{l}\text { Irrigation waters from } \\
\text { Urdana Ditch }\end{array}$ & (1) and (2) & - & - & - & - & - \\
\hline IR2 & $\begin{array}{c}\text { Irrigation waters from } \\
\text { Ebro River }\end{array}$ & (1) & - & - & - & - & - \\
\hline IR3 & $\begin{array}{l}\text { Irrigation waters from } \\
\text { Imperial Canal }\end{array}$ & (1) and (2) & - & - & - & - & - \\
\hline
\end{tabular}


some additional samples were collected for analysis at several of the points from the CHE database in order to confirm and complete their reported hydrochemistry.

As displayed in Table 1, two of the wells included in this study withdraw water from the evaporitic aquifer (WA2 and WA7), whereas the rest of them are shallower and withdraw groundwater from the alluvial aquifer, although some influence of the evaporitic groundwaters is also probable. In the case of springs and sinkhole ponds, their predominant association with one aquifer or the other is uncertain and will be assessed on the basis of their hydrochemistry.

\section{Methods for sampling and analysis}

In the sampled wells, water was continuously pumped while monitoring the variations of $\mathrm{pH}$, conductivity and temperature until their stabilization (within measurement error) before measuring the field parameters and taking the water samples for analyses. In the case of the sinkhole ponds, sampling surveys carried out in April 2009 demonstrated no variations in the hydrochemistry associated with stratification in the water column or the distance to the center of the pond. Accordingly, only one sample per pond was taken to be representative enough of the hydrochemistry at each of these points.

At each sampling point, separated samples for anion and cation analyses were taken and stored at 4oC until analyses. The elements included in the chemical analyses ( $\mathrm{Na}, \mathrm{Ca}, \mathrm{Mg}, \mathrm{K}, \mathrm{Cl}$, sulfate and alkalinity) are the major ions in the studied system, according to the available geological and mineralogical information. Based on duplicate analytical determinations, the uncertainty associated with the reported values for these elements in the samples specifically taken for this study is estimated to be generally within $\pm 8 \%$. Samples for cation analyses were filtered through $0.1 \square \mathrm{m}$ and acidified to a $\mathrm{pH}$ lower than 1 with ultrapure $\mathrm{HNO} 3$, whereas samples for anion and alkalinity analyses were stored unfiltered and unacidified. Temperature was measured in situ with a thermometer (accuracy $0.1 \mathrm{oC}$ ). The $\mathrm{pH}$ value was determined by a combined glass electrode with automated temperature correction, calibrated on a regular basis with standard buffer solutions of $\mathrm{pH} \mathrm{4,7}$ and 10 . The reported accuracy for $\mathrm{pH}$ measurements is $\pm 0.05 \mathrm{pH}$ units. Electrical conductivity was measured by using a conductivity meter with automated temperature correction.

Alkalinity and chloride contents were determined by titration with a Mettler titrator with end-point electrode. Alkalinity measurements were carried out less than 24 hours after sampling. According to the hydrogeochemical characteristics of our samples, total and carbonate alkalinity can be considered as equivalent. Sulfate concentrations were determined by colorimetry using a modification of the Nemeth method (Nemeth, 1963). Sulfate and chloride concentrations were analysed within 3-4 weeks after sample collection. Inductively Coupled Plasma-Atomic Emission Spectrometry (ICP-AES) was used for the analyses of cations ( $\mathrm{Ca}, \mathrm{Mg}, \mathrm{Na}$ and $\mathrm{K})$.

Geochemical calculations that will be discussed throughout this work have been performed with the PHREEQC code (Parkhust and Appelo, 2013) using the WATEQ4F thermodynamic database (Ball and Nordstrom, 2001) included in the PHREEQC package. Thermodynamic data for glauberite from the pitzer.dat database distributed with the PHREEQC code have been added to the WATEQ4F database. The calculated charge balance error for the reported samples, as calculated with the PHREEQC code, is generally below $5 \%$ and never above $10 \%$.

\section{Methods for multivariate statistical analysis}

Two different multivariate statistical analysis techniques were applied to the study of the hydrochemical dataset generated during this work: Principal Component Analysis (PCA) and Hierarchical Cluster Analysis (HCA). These techniques have been extensively applied to different types of geological problems and, particularly, they have been used to identify processes or environmental features controlling the behaviour of large hydrochemical datasets in different types of geological systems, including karst systems (López-Chicano et al., 2001; Moore et al., 2009 and references therein; Dassi, 2011; Barbera and Andreo, 2012; Bicalho et al., 2012 and references therein; among many others).

For PCA, all hydrochemical data (except $\mathrm{pH}$ ) were log-transformed prior to the statistical analyses, so that they more closely correspond to normally-distributed populations, and they were also autoscaled by calculating their standard scores (z scores). For HCA, different similarity/dissimilarity measurements and linkage methods have been tested, and the results suggest that Euclidean distance as similarity measurement and Paired group linkage and Ward's method produced the most distinctive groups. Dendrograms have been interpreted based on visual examination and according to the water types described previously.

Both PCA and HCA have been applied to the whole hydrochemical dataset, without separating samples from different locations or supposedly belonging to different water types. This allows that these features, if actually present in the studied system, emerge independently from the statistical analysis. 
TABLE 2 General hydrochemical features of the whole dataset used in this study. TDS: total dissolved solids; EC: electric conductivity; Temp: temperature; Alk: alkalinity (as HCO3-; Stdev: standard deviation; Min: minimum value; Max: maximum value; Q1; 1st quartile; Q3: 3rd quartile; P90, P95 and P99 are the values of the percentiles 90, 95 and 99, respectively.

\begin{tabular}{cccccccccc}
\hline & Mean & Stdev & Min & Max & Q1 & Q3 & P90 & P95 & P99 \\
\hline TDS (mg/l) & 1591 & 1056 & 305 & 6129 & 866 & 2163 & 3253 & 3482 & 5577 \\
$\mathrm{pH}$ & 7,25 & 0,43 & 6,52 & 8,57 & 7,00 & 7,31 & 8,09 & 8,20 & 8,40 \\
$\mathrm{Temp}\left({ }^{\circ} \mathrm{C}\right)$ & 16,2 & 3,6 & 3,4 & 26,1 & 15,4 & 17,8 & 19,4 & 21,8 & 24,2 \\
$\mathrm{EC}(\mathrm{M} \cdot \mathrm{cm})$ & 2296 & 1275 & 635 & 8040 & 1450 & 3080 & 4010 & 4850 & 6630 \\
$\mathrm{Alk}(\mathrm{mg} / \mathrm{l})$ & 346 & 78 & 164 & 644 & 321 & 386 & 409 & 446 & 608 \\
$\mathrm{Ca}(\mathrm{mg} / \mathrm{l})$ & 275 & 159 & 71 & 805 & 174 & 309 & 542 & 624 & 745 \\
$\mathrm{Cl}(\mathrm{mg} / \mathrm{l})$ & 389 & 323 & 65 & 1922 & 204 & 483 & 698 & 1144 & 1617 \\
$\mathrm{~K}(\mathrm{mg} / \mathrm{l})$ & 6,2 & 4,2 & 1,8 & 36,4 & 3,3 & 7,4 & 11,0 & 12,7 & 23,7 \\
$\mathrm{Mg}(\mathrm{mg} / \mathrm{l})$ & 46 & 25 & 7 & 168 & 33 & 51 & 68 & 103 & 153 \\
$\mathrm{Na}(\mathrm{mg} / \mathrm{l})$ & 278 & 226 & 48 & 1277 & 140 & 372 & 501 & 881 & 1106 \\
$\mathrm{SO}_{4}(\mathrm{mg} / \mathrm{l})$ & 580 & 473 & 96 & 2044 & 273 & 651 & 1474 & 1587 & 2027 \\
\hline
\end{tabular}

\section{RESULTS AND DISCUSSION}

\section{General hydrochemical features of the Ebro alluvial waters}

The general hydrochemistry of the studied portion of the Ebro alluvial-karst aquifer system in the surroundings of Zaragoza city is displayed in Table 2. The observed hydrochemistry for all the points corresponds to $\mathrm{Cl}-\mathrm{SO} 4-\mathrm{Na}-$ $\mathrm{Ca}$-waters with $\mathrm{pH}$ values around 7.2 but varying between 6.5 and 8.6. As a general trend, the highest $\mathrm{pH}$ values are measured in surface waters used for irrigation (points IR1, IR2 and IR3 from Table 1), which are also among the points displaying the lowest alkalinity and conductivity values (Table 3 ). There is a wide TDS variation among different sampling points, roughly ranging between 300 and $6,000 \mathrm{mg} / \mathrm{l}$. Such variations are also frequently found among different samples from the same sampling point, as shown by the large standard deviations calculated for some of them (Table 3 ).

\section{Application of Principal Component Analysis (PCA)}

PCA has been applied to identify the main variables responsible for the general hydrochemistry of the studied dataset and the possible groups of samples based on their hydrochemistry. After preliminary tests, temperature and dissolved potassium data were excluded from the analysis because their inclusion caused a clear decrease (around 10\%) in the percentage of variance explained by the two first principal components without changing substantially the results and interpretations. Therefore, PCA was finally carried out using the following hydrochemical variables: $\mathrm{pH}$, TDS and molar dissolved contents of $\mathrm{Na}, \mathrm{Cl}, \mathrm{Ca}, \mathrm{Mg}$, sulfate and alkalinity (as $\mathrm{HCO} 3-$ ).
The results obtained by PCA application are shown in Figure 3A and B. Two principal components (PC1 and PC2) were identified explaining about 66 and $20 \%$ of the total variance, respectively. Consistently with the Kaiser criterion (Kaiser, 1960), the rest of the components were considered not significant due to their low eigenvalues $(<1)$ and of the low percentage of variance explained by them (below 8\%).

In the light of the PCA results, the main processes explaining the variance of hydrochemical data in the Ebro alluvial-karst aquifer waters are related to the increase in the amount of dissolved solids. This is suggested by the association of TDS and concentrations of $\mathrm{Na}, \mathrm{Cl}, \mathrm{Ca}$ and sulfate as the main variables included in $\mathrm{PC} 1$ which, as indicated above, explained almost $70 \%$ of the total variance. As shown in Figure 3B, the loadings for all these variables in $\mathrm{PC} 1$ are about 0.4 . The most probable processes controlling the evolution of these variables in the studied area are the dissolution of halite and gypsum/ anhydrite. This issue is further assessed in the following sections.

With regard to $\mathrm{PC} 2$, the main variables included are $\mathrm{pH}$ and alkalinity (Fig. 3B), with similar absolute loadings in this component of about 0.6. Since the fraction of variance explained by PC2 (around 20\%) is much smaller than for $\mathrm{PC} 1$, it can be inferred that the influence of processes responsible for alkalinity and $\mathrm{pH}$ variations in the system is minor compared to the ones causing salinity increase. Given the reported mineralogy in the alluvial and evaporitic aquifer, the most probable processes responsible for the alkalinity and $\mathrm{pH}$ variations in the system seem to be carbonate dissolution (mainly calcite and dolomite) and input/loss of $\mathrm{CO} 2(\mathrm{~g})$. The 
TABLE 3 Average hydrochemical features for each of the selected sampling points included in this study.

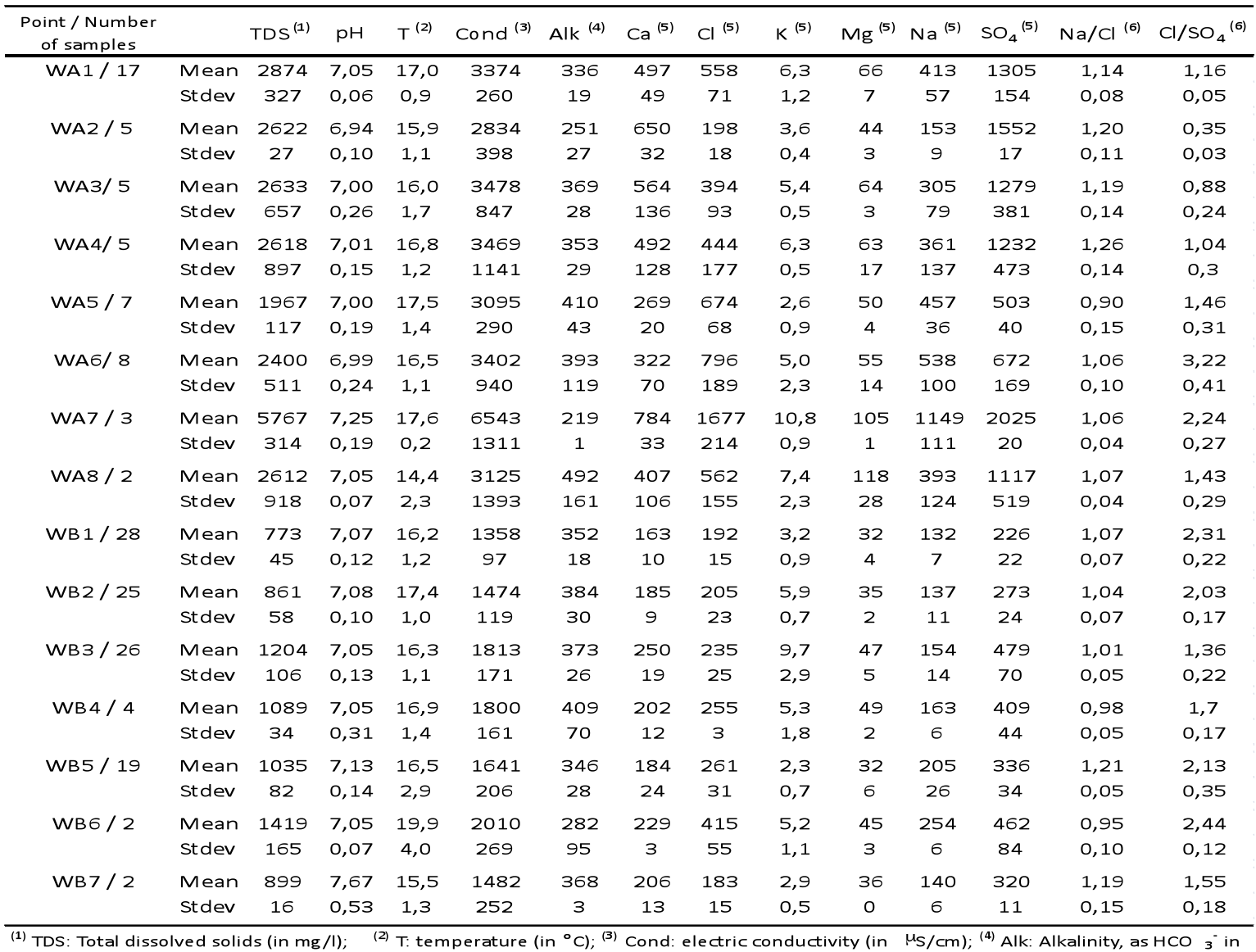

$\mathrm{mg} / \mathrm{l}$; ${ }^{(5)}$ all values in $\mathrm{mg} / \mathrm{l}$; ${ }^{(6)}$ molar ratios

Point / Number of samples

(a)

SA1/13

SA $2 / 7$

$\begin{array}{cccccc}\text { Mean } & 1922 & 6,94 & 16,4 & 2996 & 406 \\ \text { Stdev } & 106 & 0,21 & 1,9 & 326 & 31\end{array}$

SA3 / 7 Stdev

НВз /

$\operatorname{IR} 1 / 11$

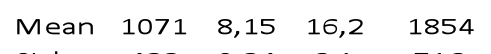

$\mathrm{IR} 2 / 5$

$\begin{array}{lllll}\text { Mean } & 891 & 8,02 & 15,2 & 1534\end{array}$
$\begin{array}{lllll}\text { Stdev } 248 & 0,26 & 8,3 & 330 & 23\end{array}$

$\mathrm{IR} 3 / 1$

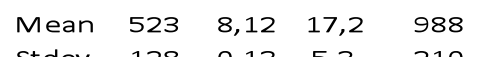
Stdev $128 \quad 0,13 \quad 5,3 \quad 210$

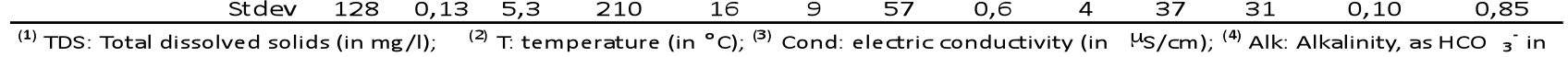
$\mathrm{mg} / \mathrm{l} ;{ }^{(5)}$ all values in $\mathrm{mg} / \mathrm{l}$; ${ }^{(6)} \mathrm{molar}$ ratios; (7) dissolved $\mathrm{K}$ concentrations were not available for some of the samples taken from the CHE database, and they have been estimated from other samples with similar TDS contents obtained at the same points during the sampling surveys specifically done for this work. 

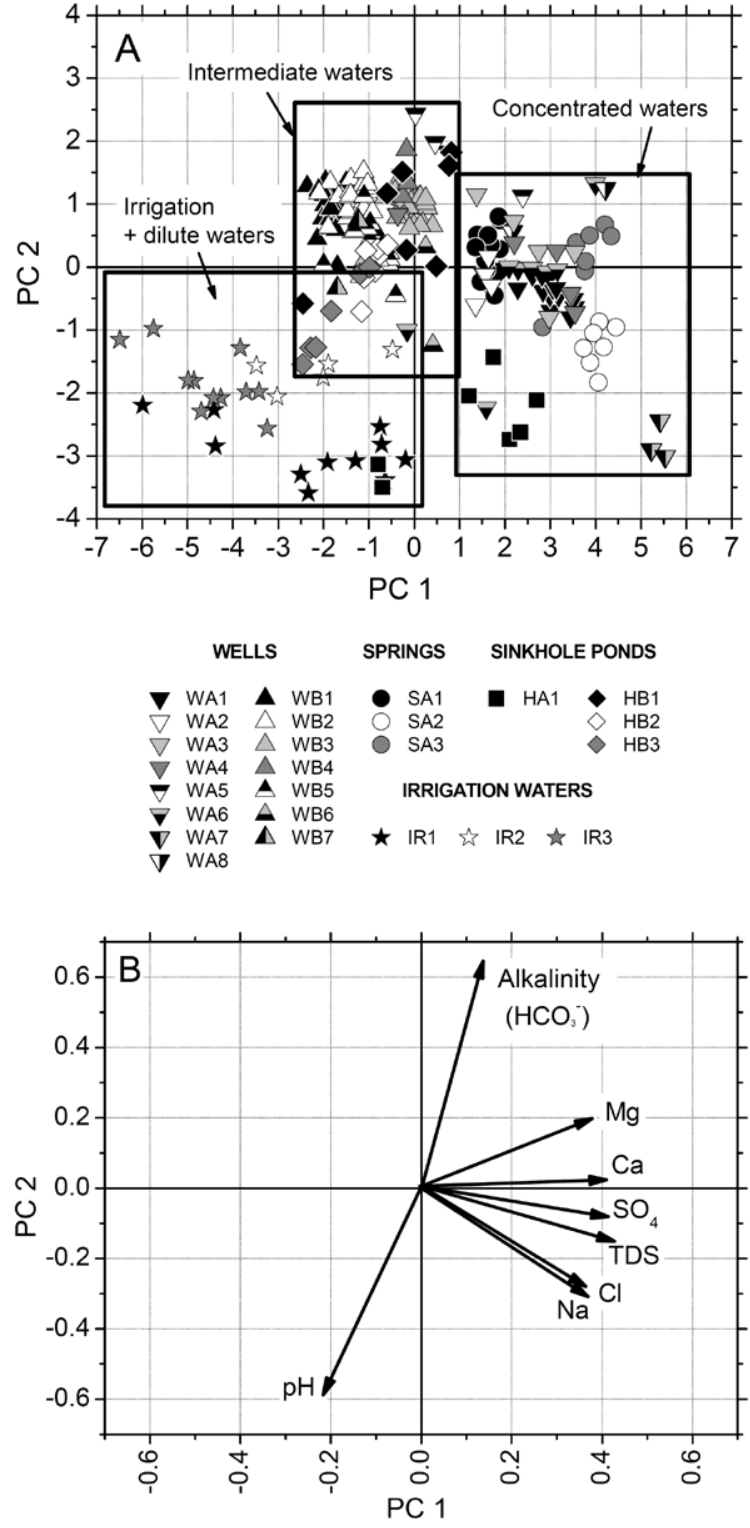

TI Summary of results of Principal Component Analysis (PCA) applied to the most significant hydrochemical variables from the studied system. A) Distribution of sample hydrochemistry in a plot of the first (PC1) vs. the second (PC2) principal components; $\mathrm{B})$ directionality and relative magnitude of influence of the variables used in the PCA on a PC1 vs. PC2 plot, indicated by arrow directions and lengths (respectively).

thermodynamic feasibility of such heterogeneous processes in the Ebro alluvial waters will be examined in the next section with the assistance of geochemical calculations.

The projection of the scores for PC1 and PC2 (Fig. 3A) shows that samples from similar types of water points plot roughly distributed in three groups: i) Irrigation waters (IR sampling points) and other dilute waters (including some samples from the sinkhole pond HA1) plot in the region of negative scores for both components. This is consistent with the recharging role of irrigation and with the small degree of interaction with the alluvial and evaporitic materials of the samples included in this group.

ii) Concentrated waters (i.e. waters with TDS content higher than the mean value for the area, identified as A-type samples; WA, SA and HA sampling points) plot in the region of the positive and largest PC1 values (Fig. $3 \mathrm{~A})$. This is consistent with the association of salinity with the PC1. This group seems to include the waters with the greatest degree of interaction with the evaporitic aquifer materials and/or groundwaters and includes, among others, the samples from the three springs (SA2, SA2 and SA3) and some of the samples from one of the sinkhole ponds (HA1) from this study.

iii) Intermediate waters between irrigation and concentrated waters (Fig. 3A). This group includes mostly the relatively dilute samples from B-type wells and boreholes, which plot over the positive region of the PC2 axis and, generally, with values between -2.5 and 1 for the PC1. Their position suggests that these waters are less affected by processes leading to salinity increase than concentrated waters but similarly or even more affected by the processes responsible for the alkalinity variations (PC2 values sometimes larger than for concentrated waters). This group probably represents a variable degree of interaction between the groundwaters of the alluvial and evaporitic aquifers and includes most of the samples from the sinkhole ponds selected for this study.

As explained, the samples corresponding to sinkhole ponds are widely scattered among the three groups described above. In some cases, this dispersion also occurs for different samples from the same sampling point (Fig. 3A). Since sinkhole ponds potentially represent windows in the alluvial aquifer interacting with the underlying evaporitic karst system, their large hydrochemical variability points towards the existence of also variable interaction processes.

\section{Application of Hierarchical Cluster Analysis (HCA)}

For the application of HCA to the dataset from the Ebro alluvial-karst aquifer system, two different cluster analyses have been carried out:

i) Clustering of samples based on their hydrochemical features, in order to detect possible groupings of sampling points. 


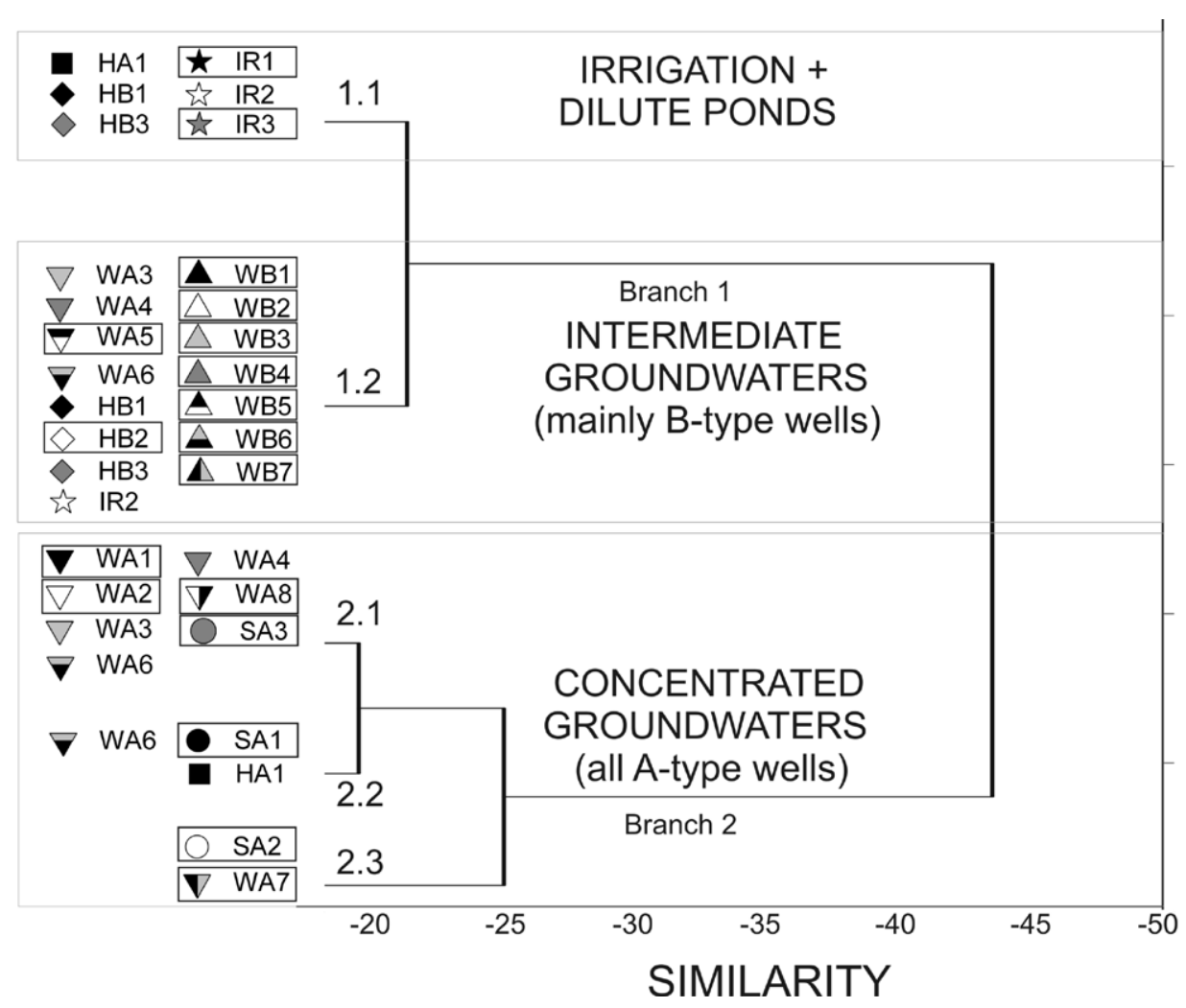

TABLE 4 Simplified results from Hierarchical Cluster Analysis (HCA) applied to samples and sampling points of the studied Ebro alluvial waters. For a better visualisation of results, only clustering for similarities above -15 and sampling points (instead of individual samples) are shown. Sampling point names surrounded by a rectangle are the ones for which every single sample falls into the displayed grouping, whereas sampling point names without a rectangle indicate than some of the samples from those points belong to different cluster branches. Branches and subbranches have been numbered and are described in detail in the text.

ii) Clustering of hydrochemical variables, including dissolved element contents, calculated saturation indexes with respect to the main possible mineral phases reported for the study area (halite, gypsum, calcite, dolomite) and calculated partial pressures of $\mathrm{CO} 2(\mathrm{~g})$ in equilibrium with the samples. This will allow identifying the possible controlling geochemical processes in the system (mineral dissolution/precipitation or $\mathrm{CO} 2(\mathrm{~g})$ input/loss).

For the clustering of samples, the selected variables were the same ones included in the previous PCA. HCA using Ward's method leads to a dendrogram in which five subbranches are individualized (Fig. 4). As expected from PCA results, the variables included in the PC1 seem to play a major role in the clustering of those points. Two sample sets are separated at similarities about -44 , corresponding to the following main branches indicated in Figure 4:

i) Branch 1: dilute groundwaters. From this major branch, two subbranches are separated at similarities about -22: subbranch 1.1, which corresponds to the most dilute waters in the area (most irrigation waters and dilute samples from ponds), and subbranch 1.2, which groups intermediate waters mostly from B-type wells. These subgroups match almost perfectly the corresponding ones in the PCA (Fig. 3A), which provides additional support for the results and of both multivariate analyses.

ii) Branch 2: concentrated groundwaters, hydrochemically closer to the features of the evaporitic aquifer groundwaters. Two dendrogram subbranches (identified as 2.1 and 2.2 in Fig. 4) are separated at a similarity value around -19 , each of them grouping samples with clearly different $\mathrm{Cl}$ :SO4 ratios, as will be explained in the next section with the assistance of ion correlations. Apart from these two subbranches, there is another one (identified as 2.3 in Fig. 4) only grouping the samples from points SA2 and WA7, which are the most clearly related to the evaporitic aquifer in the area east of Zaragoza city.

As described for the PCA results, samples from sinkhole ponds are distributed among three of the five described subbranches (Fig. 4), ranging from concentrated to very dilute waters (even for samples from the same sampling point in the case of sinkhole pond HA1). Their hydrochemistry could be attributed to mixing 


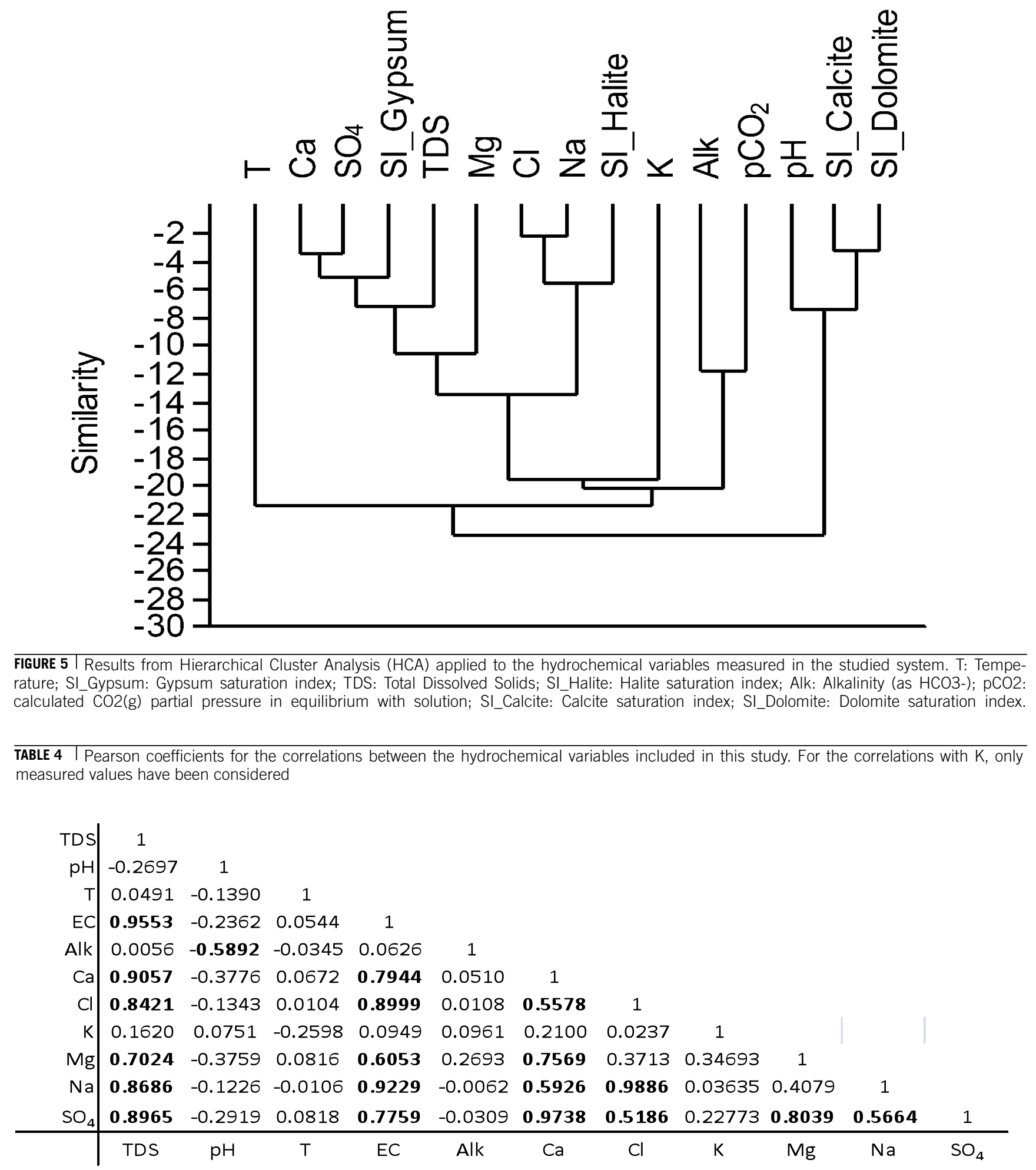

TABLE 4 I Pearson coefficients for the correlations between the hydrochemical variables included in this study. For the correlations with $\mathrm{K}$, only measured values have been considered 
between highly variable contributions from recharge/ irrigation waters interacted with the alluvial materials and groundwater discharge from the underlying evaporitic bedrock.

With regard to the clustering of hydrochemical variables (Fig. 5), the results are in good agreement with the interpretations obtained based on PCA. As displayed in Figure 5, three main branches are obtained in the dendrogram for similarities lower than -21 :

i) The first dendrogram branch is represented only by temperature (Fig. 5), which is consistent with the poor correlation obtained between this parameter and the rest of the hydrochemical variables included in this study (Table 4).

ii) The second branch includes most of the measured hydrochemical variables. The saturation indexes with respect to halite and gypsum are included in the same dendrogram subbranches as their corresponding contents of dissolved elements ( $\mathrm{Na}-\mathrm{Cl}$ and $\mathrm{Ca}-\mathrm{SO} 4$, respectively; Fig. 5). This suggests that the dissolution of both minerals, mainly in the evaporitic aquifer according to the mineralogical information, plays a key role on the hydrochemical features of the studied Ebro alluvial-evaporitic system. According to HCA results, TDS contents seem to be more related to gypsum/anhydrite dissolution processes than to halite dissolution, which would be consistent with the predominance of gypsum/anhydrite in the evaporitic bedrock in this area. With regard to the dissolved contents of $\mathrm{Mg}$, they are linked to the same subbranch grouping TDS and gypsum/anhydrite dissolution (Fig. 5), which suggests that the dissolution of the main mineral sources for this element is also taking place in the evaporitic aquifer. Potassium dissolved concentrations seem to be weakly linked to the rest of hydrochemical variables in this branch, which is in agreement with their weak correlations (Table 4) and suggests a completely different hydrochemical control of this element in the system. Finally, alkalinity contents and calculated $\mathrm{pCO} 2$, which are grouped together, are also weakly linked to the rest of variables in this branch. Their association is consistent with the good correlation between these parameters (Pearson correlation coefficient about 0.71) and could be attributed to the key role played by the pCO2 in the dissolution of carbonate minerals, which must be the main process responsible for the alkalinity contents in the groundwaters.

iii) The third dendrogram branch groups together $\mathrm{pH}$ and the saturation indexes calculated for calcite and dolomite. This is not surprising, given the key influence played by the $\mathrm{pH}$ in the heterogeneous (i.e. dissolution/ precipitation) and homogeneous (i.e. carbon speciation) processes affecting these mineral phases.
In order to confirm and explain these interpretations and groupings, the processes able to determine the salinity and alkalinity of the Ebro alluvial waters and to determine their hydrogeochemical evolution from recharge waters need to be addressed. This will be explored in the following section with the assistance of ion-ion plots, ion correlations and geochemical calculations.

\section{Ion-ion plots, ion correlations and speciation-solubility calculations}

As displayed in Table 4, and as expected from the PCA and HCA results, the hydrochemistry of the system is characterized by a good correlation between Total Dissolved Solids (TDS) values and the dissolved contents of most of the analysed elements $(\mathrm{Na}, \mathrm{Cl}, \mathrm{Ca}, \mathrm{Mg}$ and sulfate), yielding for all of them Pearson correlation coefficients above 0.7 .

Apart from this, one of the most remarkable hydrogeochemical features that can be deduced for the studied system is the good 1:1 correlation (within $\pm 5 \%$ analytical error) between the molar dissolved contents of $\mathrm{Na}$ and $\mathrm{Cl}$ in most of the studied waters, as shown in Figure 6A. This is also evidenced by the Pearson correlation coefficient between $\mathrm{Na}$ and $\mathrm{Cl}$ contents, which is around 0.99 (Table 4). Consistently with the HCA results and with the mineralogy of the evaporitic bedrock, this observation can be attributed to halite dissolution as the main source for $\mathrm{Na}$ and $\mathrm{Cl}$ in the system. However, even the water samples with the highest TDS contents and sampling waters from the evaporitic aquifer are very far from equilibrium with respect to this mineral phase (Fig. 7A). This suggests that the amounts of halite in the sampled portions of evaporitic aquifer are not large enough to attain equilibrium, which is consistent with the predominance of gypsum/anhydrite reported for these materials.

A good correlation (Pearson correlation coefficient around 0.97; Table 4) is also observed between the $\mathrm{Ca}$ and SO4 dissolved molar contents (Fig. 6B). In line with the results of HCA, the observed Ca-SO4 stoichiometry can be mostly attributed to gypsum and/or anhydrite dissolution. These phases are among the main minerals described for the evaporitic aquifer. Gypsum is also present in the alluvial deposits, derived from the gypsum bedrock that crops out in the valley margins and from direct precipitation induced by evapotranspiration. In line with this explanation, saturation states with respect to gypsum approach equilibrium with increasing TDS contents and many of the most concentrated samples from different wells and springs are already equilibrated (within the \pm 0.22 uncertainty range; Langmuir and Melchior, 1985) with respect to this mineral (Fig. 7B). 

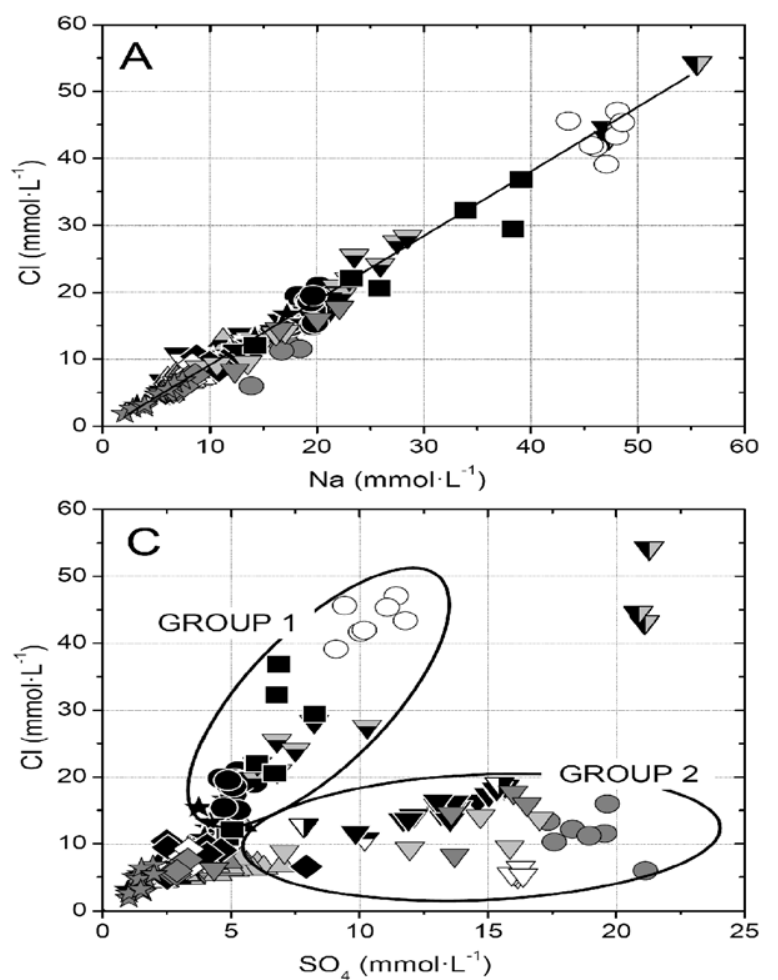

FIGURE 6 Correlation between some of the main hydrochemical parameters in the water samples from the studied system. A) Chloride vs. sodium dissolved concentrations; B) Sulfate vs. calcium dissolved concentrations; C) Chloride vs. sulfate dissolved concentrations, with indication of the two different evolution trends described in the text.

The fact that the contents of $\mathrm{Na}, \mathrm{Cl}, \mathrm{Ca}$ and $\mathrm{SO} 4$ from most of the samples are linearly located between the values from the recharge waters (irrigation) and from the groundwaters most probably associated with the evaporitic materials (Figs. 6A, B) suggests that mixing between these two water types plays a key role in the hydrochemistry of the Ebro alluvial-karst aquifer system. This is perfectly consistent with the groupings of samples inferred from PCA and HCA. Furthermore, the observed $\mathrm{Na}: \mathrm{Cl}$ and $\mathrm{Ca}: \mathrm{SO} 4$ correlations and stoichiometries suggest that other possible processes, such as glauberite dissolution or $\mathrm{Na} / \mathrm{Ca}$-exchange, generally play a minor role (compared to halite and gypsum dissolution) in the hydrogeochemical behavior of this system. If these processes were of major importance in the whole studied system, they would shift molar $\mathrm{Na} / \mathrm{Cl}$ and $\mathrm{Ca} / \mathrm{SO} 4$ ratios towards values more clearly different from 1 than generally observed (as displayed, for instance, by the samples from the spring SA3; Fig. 6A, B). Given the large amounts of glauberite reported for the evaporitic succession, the scarce contribution of its dissolution to the groundwater hydrochemistry may be attributed to the preferential circulation of groundwater through areas where it has been replaced by secondary gypsum. Such replacement affects a thick weathering zone as much as $120 \mathrm{~m}$ deep (Salvany, 2009; Fig. 1B). For the spring SA3, its hydrochemistry is probably affected by glauberite dissolution, since glauberite beds tens of meters thick have been encountered in this specific area at shallow depths (Salvany, 2009).
Good $\mathrm{Na}: \mathrm{Cl}$ and $\mathrm{Ca}: \mathrm{SO} 4$ correlations are also observed same processes of halite and gypsum/anhydrite dissolution are also important in the areas located upstream of the studied area in the Ebro and/or in the Gállego River (Fig. 1A). Consistently, the Ebro River upstream of the studied area traverses outcrops of Paleogene halite-bearing evaporite formation (Falces and Lerín formations), whereas the Gállego River flows through the Zaragoza formation along $40 \mathrm{~km}$.

In spite of the already described strong $\mathrm{Na}: \mathrm{Cl}$ and $\mathrm{Ca}: \mathrm{SO} 4$ correlations for the whole dataset, the correlation between $\mathrm{Cl}$ and SO4 dissolved molar contents (Fig. 6C) and, therefore, the Na:SO4 and $\mathrm{Ca}: \mathrm{Cl}$ correlations (plots not shown), are much weaker (Pearson correlation coefficients below 0.6; see Table 4). A detailed examination of the plot of $\mathrm{Cl}$ vs. sulfate dissolved contents (Fig. 6C) shows two different evolution trends:

i) Chloride and sulfate contents increasing steadily and $\mathrm{Cl} / \mathrm{SO} 4$ molar ratios between 1.4 and 4.2 (Group 1 in Fig. $6 \mathrm{C}$; see values of the $\mathrm{Cl} / \mathrm{SO} 4$ ratio in Table 3 ).

ii) Low chloride contents (below 20mmol/L) independently of the dissolved sulfate concentrations and $\mathrm{Cl} / \mathrm{SO} 4$ molar ratios between 0.3 and 1.2 (Group 2 in Fig. $6 \mathrm{C}$; see values of the $\mathrm{Cl} / \mathrm{SO} 4$ ratio in Table 3 ). in the irrigation waters (Fig. 6A, B). This implies that the 

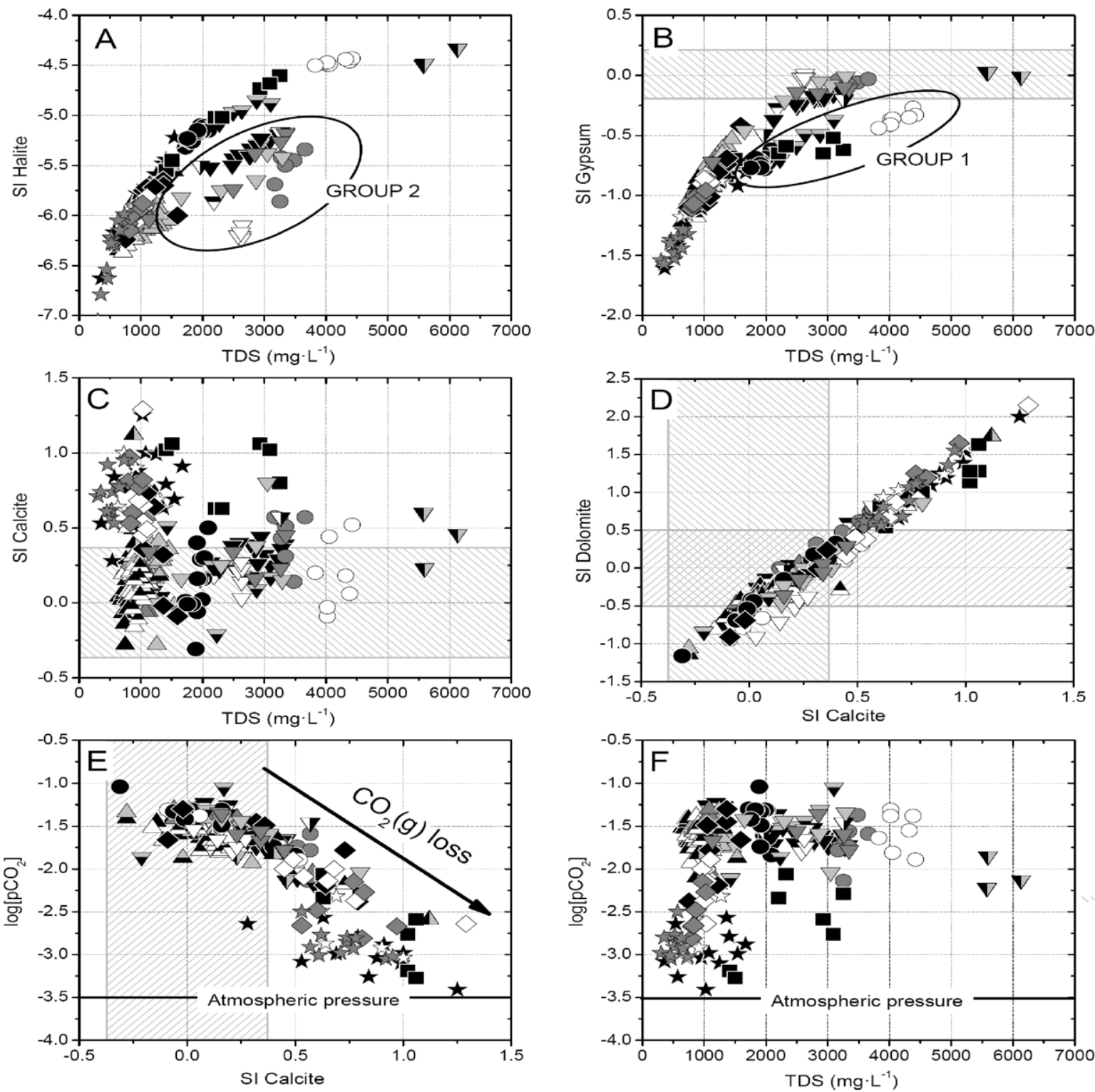

WELLS
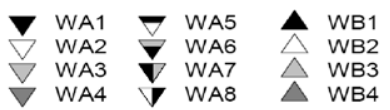

A WB5

SPRINGS

SINKHOLE PONDS IRRIGATION WATERS

- SA1 HA1

- $\mathrm{HA} 1>\mathrm{HB} 1$

FIGURE 7 Correlation between calculated saturation indexes and with hydrochemical parameters in the water samples from the studied system. A) Halite saturation index vs. Total Dissolved Solids (TDS), with indication of the two different evolution trends described in the text; B) Gypsum saturation index vs. TDS, with indication of the two different evolution trends described in the text; C) Calcite saturation index vs. TDS; D) Dolomite saturation index vs. Calcite saturation index; E) $\log [\mathrm{pCO} 2(\mathrm{~g})]$ vs Calcite saturation index; F) log[pCO2(g)] vs. TDS. The shaded areas indicate the ranges of uncertainty for the calculated saturation indexes; \pm 0.22 for gypsum (Langmuir and Melchior, 1985), \pm 0.35 for calcite and \pm 0.5 for dolomite (Plummer et al., 1990).

The only clear outliers from these groups are the samples from the WA7 point.

As can be observed in Figure 7A and B, the two groups differentiated on the basis of their dissolved $\mathrm{Cl}$ vs. SO4 evolution (Fig. 6C) also follow different trends when approaching equilibrium with respect to halite and to gypsum associated with the increase of their TDS contents. For similar TDS values, samples from Group 1 are closer to equilibrium with respect to halite but more undersaturated with respect to gypsum than samples from Group 2. Similar results, though with slightly lower saturation 
indexes, are also obtained with respect to anhydrite. These features suggest that halite and gypsum/anhydrite dissolution processes have a spatially variable contribution to the hydrochemistry of the Ebro alluvial-karst aquifer system. An examination of the geographical distribution of the samples in both groups (Fig. 1A; Fig. 6C) indicates that samples in Group 1 are all located east of Zaragoza city, whereas samples included in Group 2 correspond to the area west of Zaragoza city (except samples from point WA8). This pattern shows that, as a general trend, the sampled waters in the eastern sector have dissolved larger halite amounts than the ones from the western sector. The most probable explanation for this behavior would be the existence of highest amounts of halite (relative to gypsum/
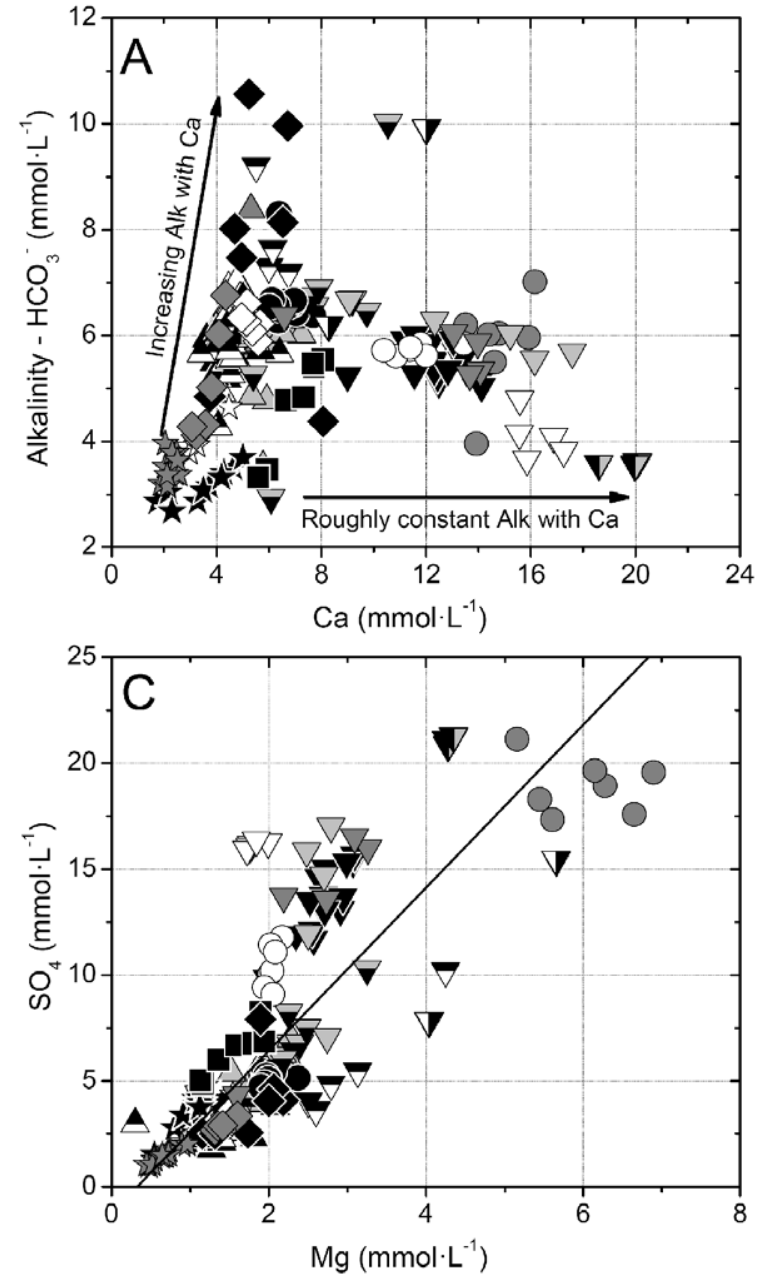

anhydrite) along the flow paths followed by groundwater that arrives at the area east of Zaragoza city.

Apart from gypsum/anhydrite dissolution, the dissolved contents of Ca may also be affected by the dissolution/ precipitation of carbonate minerals. The dissolution of these minerals (mainly calcite and dolomite) could account for the trend of increasing alkalinity and $\mathrm{Ca}$ contents observed for the samples with less than $0.008 \mathrm{~mol} / 1$ of $\mathrm{Ca}$ (Fig. 8A) this could also explain the $\mathrm{Ca} / \mathrm{SO} 4$ ratios above 1 observed for the same samples.. For the water samples with higher dissolved $\mathrm{Ca}$ contents, the roughly constant alkalinity contents observed for any given sampling point and the general trend of decreasing alkalinity for increasing

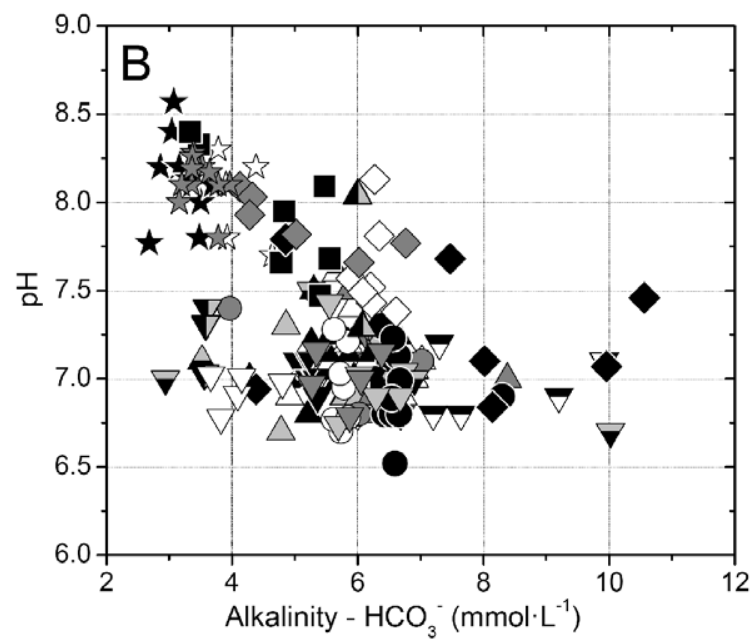

WELLS SPRINGS SINKHOLE PONDS

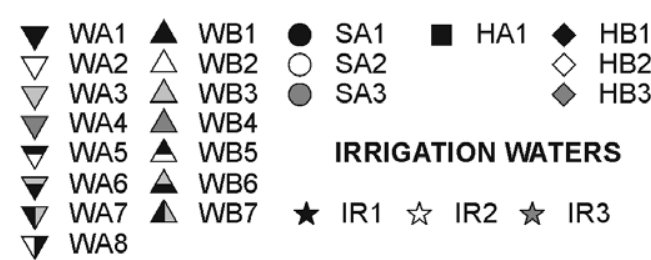

FIGURE 8 Correlation between some of the main hydrochemical parameters in the water samples from the studied system. A) Alkalinity (as HCO3-) vs. calcium concentrations, with indication of the two different evolution trends described in the text; B) pH vs. Alkalinity (as HCO3-); C) Sulfate vs. magnesium dissolved concentrations. 
Ca contents for this whole group of samples (Fig. 8A) may be attributed to the attainment of calcite equilibrium and precipitation at low alkalinity values. This can be explained by the presence of increasingly larger calcium concentrations derived from gypsum/anhydrite dissolution (common ion effect).

The apparent oversaturation with respect to calcite (Fig. 7C) and dolomite (Fig. 7D) observed in many samples (especially in the ones from sampling points in contact with atmospheric conditions, such as irrigation waters and ponds), may be attributed to $\mathrm{CO} 2(\mathrm{~g})$ degassing. This is a common situation observed when waters initially equilibrated or even undersaturated with respect to these minerals and with $\mathrm{CO} 2(\mathrm{~g})$ partial pressures (pCO2) larger than the atmospheric one are put in contact with the atmosphere during sampling or previously (López-Chicano et al., 2001; Auqué et al., 2009 and references therein). Two evidences support this explanation: i) calculated pCO2 larger than the atmospheric one (around 10-3.5atm) in equilibrium with most of the studied waters (Fig. 7E, F), and ii) presence of the largest oversaturation degrees with respect to calcite (Fig. 7E) and dolomite generally associated to samples from surface waters and close to equilibrium with atmospheric pCO2. The fact that large pCO2 are attained in most of the samples points towards the probable $\mathrm{CO} 2(\mathrm{~g})$ input to the groundwater system from soils or organic matter degradation, since other possible sources have been neither identified nor reported in earlier works.

The $\mathrm{pH}$ and alkalinity values are also correlated in the system (Fig. 8B), although their correlation is not very strong (Pearson correlation coefficient close to 0.6; Table 4). This can be attributed to the role played by the dissolution and precipitation of carbonate minerals in the control of both variables.

With regard to $\mathrm{Mg}$, the dissolved contents of this element are mainly correlated with $\mathrm{Ca}$ and sulfate contents, although this correlation is weaker than the ones described for $\mathrm{Ca}-\mathrm{SO} 4$ and $\mathrm{Na}-\mathrm{Cl}$ (Table 4; Fig. 8C). However, the presence of magnesium sulfates has not been reported for the evaporitic aquifer and its presence in trace amounts in the structure of gypsum/anhydrite (Kushnir, 1980; $\mathrm{Lu}$ et al., 1997 and references therein) cannot justify the observed dissolved concentrations in the studied system (Table 3). Therefore, in the light of the reported mineralogy for the evaporitic and alluvial aquifer, the most likely process responsible for the primary release of $\mathrm{Mg}$ to the groundwaters is the dissolution of dolomite $(\mathrm{CaMg}(\mathrm{CO} 3) 2)$.

Since the highest magnesium contents (between 50 and $100 \mathrm{mg} / \mathrm{l}$ ) are found in samples associated with the evaporitic aquifer (A-type wells and springs; Fig. 8C; Table 3 ), this process seems to have taken place more prominently in these materials. This would explain the observed correlation of $\mathrm{Mg}$ with $\mathrm{Ca}$ and sulfate and would be consistent with the HCA results. Two complementary processes may account for the large dolomite dissolution in these A-type groundwaters; i) dedolomitisation triggered by gypsum/anhydrite dissolution (e.g. Plummer et al., 1990), which is supported by the fact that these waters are close to calcite and dolomite equilibrium (Fig. 7C, D, E) independently of their closeness to gypsum equilibrium (Fig. 7B), and ii) presence of high pCO2 values (above 10-2atm; Fig. 7E, F) in equilibrium with them, which is probably caused by $\mathrm{CO} 2$ input to recharge waters from biological activity in soils.

On the contrary, samples displaying a hydrochemistry apparently more linked to the alluvial aquifer (e.g. most samples from B-type wells), generally show lower $\mathrm{Mg}$ concentrations (below $50 \mathrm{mg} / \mathrm{L}$; Table 3 ). This may be due to the existence of lower amounts of dolomite in the alluvial aquifer and/or to the lower influence of dedolomitisation.

For the dissolved molar K concentrations no significant correlation with $\mathrm{Cl}, \mathrm{SO} 4$ or other dissolved molar contents is observed (Table 4), which is consistent with the weak linkage of the contents for this element to other ions in the HCA. This behavior is not surprising, since the main sources for potassium in these groundwaters are probably aluminosilicate phases or even agricultural fertilizers, whose distribution and dissolution behavior must be very different from halite, gypsum/anhydrite and even carbonate minerals. Moreover, there are not significant differences in $\mathrm{K}$ dissolved concentrations between different water types, which prevents from knowing if the processes responsible for $\mathrm{K}$ release are preferentially linked to the alluvial aquifer or the evaporitic materials.

\section{CONCLUSIONS}

The application of multivariate analyses, ion correlations and speciation-solubility calculations to a comprehensive hydrochemical dataset from the Ebro alluvial aquifer and the underlying karstified salt-bearing evaporitic bedrock has allowed the identification of some of the main features and processes of the system. The results obtained are the first step to shed light on the inner-workings of the alluvialkarst aquifer system and to improve our understanding of the karstification processes behind sinkhole development in the area.

As suggested by PCA, HCA, ion correlations and geochemical calculations, the hydrogeochemistry of the system seems to be mainly determined by the variable 
contribution of gypsum/anhydrite and halite dissolution, showing a wide spectrum whose end members correspond to relatively fresh recharge waters (i.e. waters used for irrigation) and highly concentrated groundwaters related to the discharge of water from the evaporite karst aquifer in the Ebro alluvial aquifer. In any case, whereas equilibrium with respect to gypsum is attained by some of the groundwaters sampled in the evaporitic aquifer, halite equilibrium is far from being reached even for the most concentrated groundwaters. This may be attributed to the existence of low amounts of halite (relative to gypsum/ anhydrite) interacting with the sampled groundwaters in the evaporitic bedrock. Moreover, the relative contribution of gypsum/anhydrite and halite dissolution to the observed hydrochemistry is clearly spatially variable. As a general trend, the hydrochemistry of groundwaters from the Ebro alluvial aquifer and from the underlying evaporitic materials west from Zaragoza city seems to indicate lower interaction with halite than the ones sampled east of Zaragoza city. Another interesting mineralogical and geochemical observation is related to the minor role played by glauberite dissolution on the observed hydrochemistry, even though this mineral represents a significant proportion of the unweathered bedrock. This can be due to the extensive replacement of glauberite by secondary gypsum in most of the evaporitic deposits interacting with the groundwaters.

Apart from these karstification processes, the hydrochemistry is also influenced by the dissolution of carbonate minerals (dolomite and, possibly, calcite) triggered by the input of $\mathrm{CO} 2(\mathrm{~g})$, which is probably produced by pedogenic processes in this area with ubiquitous agricultural activities. These processes seem to be responsible for the evolution of alkalinity and $\mathrm{pH}$ buffering. Moreover, they may also increase dolomite dissolution in the evaporitic aquifer, which is suggested by the larger $\mathrm{Mg}$ concentrations observed in the groundwaters linked to the karst aquifer compared to the recharging irrigation waters. Even though dolomite dissolution may also occur in the alluvial aquifer, this process seems to be more relevant in the evaporitic materials and to be also related to dedolomitisation triggered by gypsum/anhydrite dissolution. In the case of calcite, both dissolution and precipitation of this mineral phase are probably taking place in different portions of the studied system, although this issue should be addressed further in future studies.

The hydrochemistry observed at the sampled perennial sinkhole ponds displays a large variability, from weakly evolved waters very similar to the irrigation waters, to others with geochemical features closer to the ones observed in deep wells abstracting water from the evaporite karst aquifer, which seem to be associated with discharge areas of the karst aquifer in the valley bottom alluvium.
This spatial relationship may be useful to assess sinkhole susceptibility in the area. Although the development of sinkholes in the discharge areas of carbonate karst aquifers is quite unusual (Salvati and Sasowski, 2002; Tuccimei et al., 2005), it seems to be more likely in karst systems developed in halite-bearing evaporites where discharging groundwaters are not saturated with respect to halite (e.g. Land, 2003; Yechieli et al., 2006).

\section{ACKNOWLEDGMENTS}

The authors wish to thank the Ebro Water Authority (CHE) for giving access to hydrochemical and other data used in this study. We would like to thank particularly the gentle help and support from Dr. Miguel Ángel García Vera, Felipe Delgado, Teresa Carceller and Vicente Sancho-Tello. We thank Dr. Pedro Lucha, who assisted with the fieldwork and made interesting contributions in the first steps of the project. We also thank Mr. José Ángel Navamuel (Zaragoza Municipality) for helping us to obtain permits to sample water from wells. The assistance of Enrique Oliver with some of the analytical determinations is also gratefully acknowledged. EBRONAUTAS SLL has handed over the cataraft used in the sampling survey. Dr. Acero and Dr. Asta have received economical support from the Spanish Ministry of Science and Innovation through a Research Contract from the "Juan de la Cierva Subprogram". The economical support of the European Social Fund and of the Aragon Government (DGA) through their program for financing research in Consolidated Groups is also acknowledged. The investigation has been also partially financed by the project CGL2010-16775 (Ministerio de Ciencia e Innovación and FEDER). The comments and suggestions of Dr. Dioni I. Cendón and an anonymous reviewer have greatly improved the quality of the manuscript and are gratefully acknowledged.

\section{REFERENCES}

Apaydin, A., Aktas, S.D., 2012. Assessment of groundwater quality of the Tatlicay aquifer and relation to the adjacent evaporitic formations (Cankiri, Turkey). Environmental Monitoring and Assessment, 184, 2337-2357.

Aquilina, L., Ladouche, B., Doerfliger, N., Bakalowicz, M., 2003. Deep water circulation residence time and chemistry in a karst complex. Ground Water, 41(6), 790-805.

Aquilina, L., Ladouche, B., Doerfliger, N., 2005. Recharge processes in karstic systems investigated through the correlation of chemical and isotopic composition of rain and spring-waters. Applied Geochemistry, 20, 2189-2206.

Aquilina, L., Ladouche, B., Doerfliger, N., 2006. Water storage and transfer in the epikarst of karstic systems during high flow periods. Journal of Hydrology, 327(3-4), 472-485.

Auqué, L.F., Acero, P., Gimeno, M.J., Gomez, J.B., Asta, M.P., 2009. Hydrogeochemical modeling of a thermal system and 
lessons learned for $\mathrm{CO} 2$ geologic storage. Chemical Geology, 268, 324-336.

Ball J.W., Nordstrom, D.K., 2001. User's manual for WATEQ4F, with revised thermodynamic data base and test cases for calculating speciation of major, trace, and redox elements in natural waters. USA, US Geological Survey Open File Report, 91-183.

Barbieri, M., Boschetti, T., Petitta, M., Tallini, M., 2005. Stable isotope $(2 \mathrm{H}, 18 \mathrm{O}$ and $87 \mathrm{~S} / 86 \mathrm{Sr})$ and hydrochemistry monitoring for groundwater hydrodynamics analysis in a karst aquifer (Gran Sasso, Central Italy). Applied Geochemistry, 20, 2063-2081.

Barberá, J.A., Andreo, B., 2012. Functioning of a karst aquifer from S Spain under highly variable climate conditions, deduced from hydrochemical records. Environmental Earth Sciences, 65, 2337-2349.

Beck, B.F., 2005. Soil piping and sinkhole failures. In: White, W.B. (ed.). Encyclopedia of Caves. New York, Elsevier, 523528.

Bicalho, C.C., Batiot-Guilhe, C., Seidel, J.L., Van Exter, S., Jourde, H., 2012. Geochemical evidence of water source characterization and hydrodynamic responses in a karst aquifer. Journal of Hydrology, 450-451, 206-218.

Calaforra, J.M., Pulido-Bosch, A., 1999. Gypsum karst features as evidence of diapiric processes in the Betic Cordillera, southern Spain. Geomorphology, 29, 251-264.

Chiesi, M., Waele, J.D., Paolo, F., 2010. Origin and evolution of a salty gypsum/anhydrite karst spring: The case of Poiano (Northern Apennines, Italy). Hydrogeology Journal, 18, 1111-1124.

Cooper, A.H., Gutiérrez, F., 2013. Dealing with gypsum karst problems: hazards, environmental issues and planning. In: Shroder, J. (ed.). Treatise on Geomorphology. Volume 6: Karst Geomorphology. Elsevier, 451-462.

Dassi, L., 2011. Investigation by multivariate analysis of groundwater composition in a multilayer aquifer system from North Africa: A multi-tracer approach. Applied Geochemistry, 26, 1386-1398.

Diputación General de Aragón, 2007. Atlas climático de Aragón. Gobierno de Aragón, Departamento de medio ambiente, 222pp. Available at: http://www.aragon.es/ DepartamentosOrganismosPublicos/Departamentos/ AgriculturaGanaderiaMedioAmbiente/AreasTematicas/ MA_CambioClimatico/EACCEL/LineasActuacionProyecto/ ci.07_01_Atlas_Climatico_Aragon.detalleDepartamento).

Durán, J., Garrido, E., García, M., 2005. Informe: Trabajos técnicos para la aplicación de la Directiva Marco del Agua en materia de Aguas Subterráneas. Caracterización Adicional Aluvial del Ebro-Zaragoza. Instituto Geológico y Minero de España, Dirección General del Agua. 112pp.

Fidelibus, M.D., Gutiérrez, F., Spilotro, G., 2011. Humaninduced hydrogeological changes and sinkholes in the coastal gypsum karst of Lesina Marina area (Foggia Province, Italy). Engineering Geology, 118, 1-19.

Galve, J.P., Gutiérrez, F., Lucha, P., Bonachea, J., Cendrero,
A., Gimeno, M.J., Gutiérrez, M., Pardo, G., Remondo, J., Sánchez, J.A., 2009. Sinkholes in the salt-bearing evaporite karst of the Ebro River valley upstream of Zaragoza city (NE Spain). Geomorphological mapping and analysis as a basis for risk management. Geomorphology, 108, 145-158.

Guerrero, J., Gutiérrez, F., Lucha, P., 2008a. The impact of halite dissolution subsidence on fluvial terrace development. The case study of the Huerva River in the Ebro Basin (NE Spain). Geomorphology, 100(1-2), 164-179.

Guerrero, J., Gutiérrez, F., Bonachea, J., Lucha, P., 2008b. A sinkhole susceptibility zonation based on paleokarst analysis along a stretch of the Madrid-Barcelona high-speed railway built over gypsum- and salt-bearing evaporites (NE Spain). Engineering Geology, 102, 62-73.

Guerrero, J., Gutiérrez, F., Galve, J.P., in press. Large depressions, thickened terraces and gravitational deformation in the Ebro River valley (Zaragoza area, NE Spain). Evidence of glauberite and halite interstratal karstification. Geomorphology.

Günay, G., 2002. Gypsum karst, Sivas, Turkey. Environmental Geology, 42, 387-398.

Gutiérrez, F., Galve, J.P., Guerrero, J., Lucha, P., Cendrero, A., Remondo, J., Bonachea, J., Gutiérrez, M., Sánchez, J.A., 2007. The origin, typology, spatial distribution, and detrimental effects of the sinkholes developed in the alluvial evaporite karst of the Ebro River valley downstream Zaragoza city (NE Spain). Earth Surface Processes and Landforms, 32, 912-928.

Gutiérrez, F., Calaforra, J.M., Cardona, F., Ortí, F., Durán, J. J., Garay, P., 2008a. Geological and environmental implications of the evaporite karst in Spain. Environmental Geology, 53, 951-965.

Gutiérrez,F., Guerrero, J.,Lucha, P., 2008b. Agenetic classification of sinkholes illustrated from evaporite paleokarst exposures in Spain. Environmental Geology, 53, 993-1006.

Gutiérrez, F., Johnson, K.S., Cooper, A.H., 2008c. Evaporite karst processes, landforms and environmental problems. Environmental Geology, 53, 935-936.

Gutiérrez, F., Galve, J.P., Lucha, P., Bonachea, J., Jordá, L., Jordá, R., 2009. Investigation of a large collapse sinkhole affecting a multi-storey building by means of geophysics and the trenching technique (Zaragoza city, NE Spain). Environmental Geology, 58, 1107-1122.

Jiménez-Torrecilla, N., Galve, J.P., Asta, M.P., Gómez, L., Fuentes, J., 2004. Los humedales salinos del entrono de Zaragoza: una singularidad hidrogeomorfológica. GeoTemas, 6, 115-118.

Johnson, K. S., Neal, J.T., 2003. Evaporite karst and engineering/ environmental problems in the United States. Oklahoma Geological Survey circular, 109, 353pp.

Kaçaroglu, F., Degirmenci, M., Cerit, O., 2001. Water quality problems of a gypsiferious watershed: Upper Kizilirmak Basin, Sivas, Turkey. Water, air and soil pollution, 128, 161180.

Kaiser, H.F., 1960. The application of electronic computers to factor analysis. Educational and Psychological Measurement, $20,141-151$. 
Klimchouk, A., Lowe, D., Cooper, A., Sauro, U., 1996. Gypsum karst of the World. International Journal of Speleology, 25(34), 307pp.

Kushnir, J., 1980. The coprecipitation of strontium, magnesium, sodium, potassium and chloride ions with gypsum. An experimental study. Geochimica et Cosmochimica Acta, 44, 1471-1482.

Lamont-Black, J., Younger, P.L., Forth, R.A., Cooper, A.H., Bonniface, J.P., 2002. A decision-logic framework for investigating subsidence problems potentially attributable to gypsum karstification. Engineering Geology, 65, 205-215.

Lamont-Black, J., Baker, A., Younger, P.L., Cooper, A.H., 2005. Utilising seasonal variations in hydrogeochemistry and excitation-emission fluorescence to develop a conceptual groundwater flow model with implications for subsidence hazards: an example from Co. Durham (UK), Environmental Geology, 48, 320-335.

Land, A.L., 2003. Evaporite karst and regional groundwater circulation in the Lower Pecos Valley of Southeastern New México. In: Johnson, K.H., Neal, J.T. (eds.). Evaporite karst and engineering/environmental problems in the United States. Oklahoma Geological Survey Circular, 109, 227-232.

Langmuir, D., Melchior, D., 1985. The geochemistry of Ca, Sr, $\mathrm{Ba}$ and Ra sulfates in some deep brines from the Palo Duro Basin, Texas. Geochimica Cosmochimica Acta, 49, 24232432.

López-Chicano, M., Bouamama, M., Vallejos, A., Pulido-Bosch, A., 2001. Factors which determine the hydrogeochemical behaviour of karstic springs. A case study from the Betic Cordilleras, Spain. Applied Geochemistry, 16, 1179-1192.

Lu, F.H., Meyers, W.J., Schoonen, M.A.A., 1997. Minor and trace element analyses on gypsum: an experimental study. Chemical Geology, 142(1-2), 1-10.

Martín, P., 1993. Hidrogeología del Campo Nacional de Maniobras y Tiro de San Gregorio. MSc Thesis. Universidad Politécnica de Catalunya, Unpublished, 88pp.

Moore, P.J., Martin, J.B., Screaton, E.J., 2009. Geochemical and statistical evidence of recharge, mixing, and controls on spring discharge in an eogenetic karst aquifer. Journal of Hydrology, 376, 443-455.

Nemeth, K., 1963. Photometric determination of sulphate in soil extracts. Zeitschrift für Pflanzenernährung, Düngung 103, 193196.

Ninyerola, M., Pons, X., Roure, J.M, 2005. Atlas Climático Digital de la Península Ibérica. Metodología y aplicaciones en bioclimatología y geobotánica. Bellaterra, Universidad Autónoma de Barcelona, 44pp.

Omelon, C.R., Pollard, W.H., Andersen, D.T., 2006. A geochemical evaluation of perennial spring activity and associated mineral precipitates at Expedition Fjord, Axel Heiberg Island, Canadian High Arctic. Applied Geochemistry, 21, 1-15.

Ortí, F., Salvany, J.M., 1997. Continental evaporitic sedimentation in the Ebro Basin during the Miocene. In: Busson, G., Schreiber, B.Ch. (eds.). Sedimentary deposition in rift and foreland basins in France and Spain. New York, Columbia University Press, 420-429.

Parkhurst, D.L., Appelo, C.A.J., 2013. Description of input and examples for PHREEQC version 3-A computer program for speciation, batch-reaction, one-dimensional transport, and inverse geochemical calculations. U.S. Geological Survey Techniques and Methods, book 6, chapter A43, 497pp. Available only at http://pubs.usgs.gov/tm/06/a43/

Plummer, N., Busby, J., Lee, R., Hanshaw, B., 1990. Geochemical modeling of the Madison aquifer in parts of Montana, Wyoming and South Dakota. Water Resources Research, 26, 1981-2014.

Quirantes, J., 1978. Estudio sedimentológico y estratigráfico del Terciario continental de los Monegros. Zaragoza, Institución Fernando el Católico (CSIC), 200pp.

Sánchez, J.A., Jiménez, N., Galve, J.P., Asta, M.P., 2004. Estudio hidrogeológico de la subsidencia y los humedales salinos en el entorno de Zaragoza. Unidad de Montes y Áreas Naturales, Excmo. Zaragoza, Ayuntamiento de Zaragoza, Unpublished Report.

Salvany, J.M., García-Veigas, J., Ortí, F., 2007. Glauberite-halite association of the Zaragoza Gypsum Formation (Lower Miocene, Ebro Basin, NE Spain). Sedimentology, 54, 443-467.

Salvany, J.M., 2009. Geología del yacimiento glauberítico de Montes de Torrero (Zaragoza). Zaragoza, Prensas Universitarias de Zaragoza, 80pp.

Salvati, R., Sasowsky, I.D., 2002. Development of collapse sinkholes in areas of groundwater discharge. Journal of Hydrology, 264, 1-11.

Torrescusa, S., Klimowitz, J., 1990. Contribución al conocimiento de las evaporitas miocenas (Formación Zaragoza) de la Cuenca del Ebro. In: Ortí, F., Salvany, J.M. (eds.). Formaciones evaporíticas de la Cuenca del Ebro y cadenas periféricas y de la zona de Levante. Barcelona, Empresa Nacional de Residuos Radiactivos, S.A. (ENRESA) and Departament de Geoquimica, Petrologia i Prospecció Geològica of the University of Barcelona (GPG), 120-122.

Tuccimei, P., Salvati, R., Capelli, G, Delitala, M.C., Primavera, P., 2005. Groundwater fluxes into a submerged sinkhole area, Central Italy, using radon and water chemistry. Applied Geochemistry 20, 1831-1847.

Waltham, T., Bell, F., Culshaw, M., 2005. Sinkholes and subsidence. Chichester, Springer, 382pp.

Williams, P., 2004. Dolines. In: Gunn, J. (ed.). Encyclopedia of Caves and Karst Science. New York, Fitzroy Dearborn, 304310.

Yechieli, Y., Abelson, M., Bein, A., Crouvi, O., Shtivelman, V., 2006. Sinkhole "swarms" along the Dead Sea coast: Reflection of disturbance of lake and adjacent groundwater systems. Geological Society of America Bulletin, 118(9-10), 1075-1087.

Manuscript received November 2012; revision accepted September 2013; published Online October 2013. 